$$
\text { Cont.920104-.8 }
$$

SAND91-1580A

\title{
A CHARGED PARTICLE TRANSPORT ANALYSIS OF THE DOSE TO A SILICON-GERMANIUM THERMOELECTRIC ELEMENT DUE TO A SOLAR FLARE EVENT*
} SAND--91-1580C

\author{
Vincent J. Dandini \\ Sandia National Laboratories \\ Box 5800 \\ Albuquerque, NM 87185-5800 \\ $505-845-7032$
} DE91 016650

\begin{abstract}
A version of the BRYNTRN baryon transport code written at the NASA Langley Research Center has been used to analyze the dose to a typical space reactor thermoelectric (TE) element due to a solar flare event. The code has been used in the past to calculate the dose/dose equivalent distributions to astronauts due to solar flares. It has been modified to accommodate multiple layers of spacecraft and component material. Differential and integrated doses to the TE element are presented and discussed.
\end{abstract}

\section{INTRODUCTION}
The fundamental nature of many space nuclear power systems makes them susceptible to performance degradation due to the interaction of space radiation on a microscopic level with their basic materials. Changes in semiconductor materials due to space radiation bombardment can have varying effects ranging from minor changes in performance to complete system failure resulting in total mission loss.
Solar flare events represent a major radiation hazard to crews and equipment beyond the earth's magnetic field. The radiation output from these events consists almost exclusively of high energy protons with maximum energies in the GeV range. Interactions of these particles with spacecraft materials produce energetic secondary particles and recoil nuclei, which also contribute to radiation dose.
This paper reports the results of analyses of dose due to a solar event to the thermoelectric element (TE) of a. $100 \mathrm{~kW}(\mathrm{e})$ class space nuclear power system. This problem was considered because of the possible location of the TE's in some conceptual system configurations [1]. One proposed configuration has the TE modules located behind the fixed heat pipe radiators with no
shielding other than the heat pipes themselves [2]. and

*This work was supported by the U.S. Department of Energy
Contract DE-AC04-76DP00789. DISTRIBUTION OF THIS DOCUMENT IS UNLIMITED 


\section{DISCLAIMER}

This report was prepared as an account of work sponsored by an agency of the United States Government. Neither the United States Government nor any agency Thereof, nor any of their employees, makes any warranty, express or implied, or assumes any legal liability or responsibility for the accuracy, completeness, or usefulness of any information, apparatus, product, or process disclosed, or represents that its use would not infringe privately owned rights. Reference herein to any specific commercial product, process, or service by trade name, trademark, manufacturer, or otherwise does not necessarily constitute or imply its endorsement, recommendation, or favoring by the United States Government or any agency thereof. The views and opinions of authors expressed herein do not necessarily state or reflect those of the United States Government or any agency thereof. 


\section{DISCLAIMER}

Portions of this document may be illegible in electronic image products. Images are produced from the best available original document. 
METHOD

The analyses were performed using a version of the BRYNTRN baryon transport code [3]. Two orientations of the TE module to the solar flare fluence were considered: (1) particle transport through the radiator and the several layers of the TE module to the SiGe thermoelectric element (referred to here as the stacked case) and (2) particle transport through the radiator and then immediately impinging on the element (side exposure case).

As configured for these analyses, the code solves the multigroup charged particle transport equations through as many as 20 layers of material using the straight ahead approximation [3]. The calculation includes secondary protons and neutrons and high $\mathrm{Z}$, high energy (HZE) recoil particles. Because recoil particles deposit their energy at essentially their point of formation, the recoil dose in the last layer is calculated only for HZE particles produced in that layer.

In the present analyses, the code-calculated differential dose at the mesh points was fitted to an appropriate curve with correlation coefficients in the .999 regime. This curve was then integrated over the total target thickness to obtain the total dose to the TE module's sige element.

\section{RESULTS}

The results presented here are for the August 1972 solar flare event. This flare, while having a relatively low maximum particle energy, had a very high fluence and is often included in spacecraft survivability studies [4].

The dose vs. depth results as calculated for the stacked and side exposures are given in Figures 1 and 2 respectively. Total doses are summarized in the table below.

Thermoelectric Element Doses [rads (SiGe)]

\begin{tabular}{lrr} 
Particles & Stacked & \multicolumn{1}{c}{ Side } \\
Primary & 778.14 & 633.17 \\
Secondary & 18.00 & 14.45 \\
Total & 796.14 & 647.62
\end{tabular}

At first glance, the results appear contradictory in that the stacked exposure, whose multiple layers provide shielding that the side exposure model does not, has a higher dose. The results however, must be viewed in terms of the definition of dose as energy deposited per unit mass. For these straight ahead analyses, this definition leads to a dose given by

$$
D_{\text {tot }}=\frac{\int_{0}^{Y_{\text {tot }}} D(y) d y}{Y_{\text {tot }}}
$$


where: $\quad$ tot $=$ total dose,

$D(y)=$ dose as a function of depth $Y$ in the target, and

Ytot $=$ total target thickness.

For the stacked exposure, the total thickness of the TE element in the direction of the particle fluence was $1.49 \mathrm{~g} / \mathrm{cm}^{2}$. For the side exposure, the thickness was approximately 5 times that value. Thus, Ytot in Equation (1) is larger for the side exposure case. The dose for the first $1.49 \mathrm{~g} / \mathrm{cm}^{2}$ of the side exposure case was found to be 2181 rads or 2.7 times that of the stacked exposure case.

The full paper will consider several solar flare events and will present a brief derivation of the equation used to determine the integral doses to facilitate understanding of differences in absorbed dose between the side and stacked models.

\section{CONCLUSION}

Based on discussions with technical experts in the field, the doses calculated for the August 1972 flare event would not present a threat to the function of a sige thermoelectric element or any other Sige bulk device [5].

While doses of this magnitude to electronic devices would not present a threat to their function [5], the nature of the dose calculation dictates that the results presented here cannot be extrapolated to the very small thickness of these components. A set of specific calculations for electronic components that consider the thin profile of these devices before a similar conclusion is drawn regarding their operation should be performed.

\section{Acknowledgements}

This work was performed as a project for a graduate level problems course (Chemical and Nuclear Engineering 552) at the University of New Mexico under the supervision of Dr. Anil $\mathrm{K}$. Prinja. His guidance during the project is gratefully acknowledged.

The problem was suggested by Dr. James H. Lee of Sandia National Laboratories.

The author gratefully acknowledges the advice and guidance of Dr. John W. Wilson, Dr. Lawrence W. Townsend, and Mr̈. John E. Nealy of the NASA Langley Research Center, all of whom furnished invaluable guidance on the operation and characteristics of the BRYNTRN code. 


\section{References}

1. Private communication with Dr. James H. Lee, Sandia National Laboratories.

2. Terrill, W., Haley, V., Thermoelectric Converter for SP-100 Space Reactor Power System, Proceedings of the 21st Intersociety Energy Conversion Engineering Conference, San Diego CA, 1986

3. Wilson, J., et al, BRYNTRN, A Baryon Transport Model, NASA Technical Paper 2887, National Aeronautics and Space Administration, 1989

4. Private Communication with Mr. L. Connell, Sandia National laboratories.

5. Private Communication with Messrs Frank V. Thome and Donald B. King, Sandia National Laboratories.

\section{DISCLAIMER}

This report was prepared as an account of work sponsored by an agency of the United States Neither the United States Government nor any agency thereof, nor any of their Nes any warranty, express or implied, or assumes any legal liability or responsiemployees, makes any warranty, express or implied, or any information, apparatus, product, or bility for the accuracy, completeness, or usefulness of any infor process disclosed, or represents that its use would not infringe privale by trade name, trademark, ence herein to any specific commercial product, process, or service bly its endorsement, recommanufacturer, or otherwise does not necessarily constitute or imply its en thereof. The views mendation, or favoring by the United States Government or any agences reflect those of the and opinions of authors expressed herein do nof 